\title{
NOAH, THE ARK, AND THE FLOOD IN EARLY CHRISTIAN LITERATURE
}

Mark Wilson

Old and New Testament

Stellenbosch University

\begin{abstract}
This article surveys the literary traditions related to Noah, the ark, and the flood in early Christian literature. Mention of Noah, the ark, and the flood is found in five New Testament books - Matthew, Luke, Hebrews, 1 Peter, and 2 Peter-as well as in two documents in the Apostolic Fathers - 1 Clement and 2 Clement. The relevant passages in these books will be discussed seriatim. Significant historical and grammatical issues related to the texts will also be noted. Finally, the rhetorical functions - moral, homiletic, eschatological, and ecological - will be discussed. Early Christian literature depended on the Jewish Scriptures, particularly the LXX, and Intertestamental literature for the motifs and allegorisation found its own interpretations. The traditions related to Noah, the ark, and the flood were important for Jesus and the early church, and an attempt will be made to elucidate their significance for each author.
\end{abstract}

Key Words: Noah; Ark; Flood; Repentance; Judgment; Ecology

\section{Introduction}

The March 2014 release of the Hollywood blockbuster movie 'Noah' has put the subject of Noah, the ark, and the flood before a global audience once again. In Turkey the resolution of the Kurdish conflict with the PKK has allowed scholars for the first time in forty years to visit Cudi Dağ 1 , the purported resting place of the ark in some Jewish, Muslim, and Christian traditions. ${ }^{1}$ This article builds on renewed interest in the topic by surveying the literary traditions of Noah, the ark, and the flood in early Christian literature. Five of the documents - Matthew, Luke, Hebrews, 1 Peter, and 2 Peter - are found in the New Testament and generally dated to the latter half of the first century A.D. ${ }^{2}$ The other two documents - 1 Clement and 2 Clement - are found in The Apostolic Fathers and date to the early second century A.D. ${ }^{3}$ The passages in these documents related to our topic will be discussed seriatim. Significant historical and grammatical issues related to the text will also be noted. Finally, the rhetorical function of Noah, the ark, and the flood in each document will be discussed. Four functions will be elucidated: moral, homiletic, eschatological and

This changed political situation in southeastern Turkey is what prompted Şırnak University to host its first International Noah and Judi Mountain Symposium in September 2013. This article is an expanded version of my presentation at the symposium and published in its volume of symposium proceedings. I would like to thank the organizers of the symposium for the impetus to research and publish an article on this subject.

2 A discussion of the dating of these books can be found in any standard introduction of the New Testament; see D deSilva, An Introduction to the New Testament: Contexts, Methods \& Ministry Formation. Downers Grove, IL: InterVarsity Academic, 2004 ad loc.

3 A discussion of the dating of 1 and 2 Clement can be found in CN Jefford, Reading the Apostolic Fathers: An Introduction. Peabody, MA: Hendrickson, 1996 ad loc. 
ecological. Christian literature depended on the Jewish Scriptures, particularly in their Greek version the LXX, as well as Intertestamental literature for the motifs and allegorisation found its own interpretations. ${ }^{4}$ The traditions related to Noah $^{5}$ were very important for early Christians, and their significance for each writer will be explicated.

\section{Noah and the Flood in the Synoptic Gospels}

\section{Noah in the Genealogy of Jesus}

In Luke 3:36 Noah is mentioned as one of the ancestors in the genealogy of Jesus. To the ancient Jews the preservation of their heritage using genealogical tables was customary. For example, Josephus (Life 1.3) wrote that his genealogical background was to be found 'in the public records.' He likewise records in Against Apion 1.7 that Diaspora Jews would send the names of their children to Jerusalem to be recorded officially. Families of Levitical descent (the priestly line) and Davidic descent (the kingly line) were especially eager to preserve their heritage. Rabbi Hillel ( $1^{\text {st }}$ century AD) was able to confirm his descent from David using the public registries. Jesus' extensive genealogy begins in 3:23 with the words: "Now Jesus himself was about thirty years old when he began his ministry. He was the son, so it was thought, of Joseph, the son of Heli." The list contains 66 persons to Noah where in 3:36 it states: "the son of Arphaxad, the son of Shem, the son of Noah..." Nine persons follow, including his father Lamech, until the genealogy ends in 3:38 with: "the son of Enosh, the son of Seth, the son of Adam, the son of God." Luke's list from Noah to Adam follows exactly the genealogy given in 1 Chronicles $1: 1-4{ }^{6}$ There are a total of 76 persons in the genealogy of Jesus descending in reverse order from the presumed and adoptive father of Jesus, Joseph, to Adam the first man created by God. The list emphasizes not only the royal lineage of Jesus through King David (v. 31), but also his descent from the patriarchs Abraham, Isaac, Jacob, and Judah (v. 34). Luke's genealogy differs greatly from the genealogy found in Matthew 1:1-17, which begins with Abraham.

But what is Luke's purpose adding this genealogy that includes Noah? It follows the account of Jesus' baptism by John the Baptist with the subsequent descent by the Holy Spirit as a dove upon Jesus. A voice from heaven then affirms: "You are my Son whom I love; with you I am well pleased" (Luke 3:21-22). Fitzmeyer proposes this likely purpose: "the connection has rather to be sought with what precedes, since it is the genealogy of Jesus, the Son of God, whose relation to heaven was set forth in the preceding episode." 8

For a discussion of this literature see JP Lewis, A Study of the Interpretation of Noah and the Flood in Jewish and Christian Literature. Leiden, Brill: 1981:3-100.

5 For a discussion of the meaning of the name Noah, see L Bailey, 'Noah,' Biblical Archaeologist, December 1984, 225.

6 According to Jewish tradition, Ezra wrote the book of Chronicles. Whereas Ezra or a contemporary, the Chronicler probably wrote the genealogy in the latter half of the fifth century BC.

7 Matthew's genealogy flows chronologically beginning with Abraham and ascends to Jesus, thus recording only 41 names. Luke's list descends from Jesus to Abraham using 57 names. The lists overlap with the names of Shealtiel and Zerubbabel, as well as the sequence of 14 names from Abraham to David. Even the name of Joseph's father is different in Matthew - Jacob (1:16). The proposed solutions for reconciling these genealogies, as well as a detailed discussion of their differences, is given in JA Fitzmyer, The Gospel according to Luke I-IX. New York: Doubleday, 1970:488-97.

8 Fitzmyer, Luke, 498. CA Evans, on the contrary, sees the answer as relating to Adam, the last human name on the list. He writes: "Because of his universalistic emphasis, Luke wishes to trace the lineage of Jesus back to the first human being, the father of all nations... By going back to Adam, Luke finds biblical support for his presentation of Jesus as the Savior of all humankind.” Luke, Peabody, MA: Hendrickson, 1990:58. 
Thus two witnesses are given by Luke - the heavenly voice at baptism and the genealogical record - that Jesus is the chosen Son of God. ${ }^{9}$

\section{Noah in Jesus' Eschatological Teaching in Luke and Matthew}

Luke mentions Noah a second time in his Gospel in chapter 17. There, in answer to a Pharisee's question about when the kingdom of God would come, Jesus gave an extended teaching to his disciples about the conditions on earth surrounding his return (17:20-36). Those future days, by analogy, will resemble the conditions on earth during the times of Noah and Lot when God brought judgment upon the earth. ${ }^{10}$ But first he warns that "he must suffer many things and be rejected by this generation" (17:25). Jesus then goes on to state in verses 26-27: "Just as it was in the days of Noah, so also will it be in the days of the Son of Man. People were eating, drinking, marrying and being given in marriage up to the day Noah entered the ark. Then the flood came and destroyed them all." Jesus' discussion of Lot follows next (17:28-35).

In his Gospel, Matthew places Jesus' mention of Noah in a different context. During the last week in Jerusalem before his crucifixion, Jesus was teaching his disciples on the Mount of Olives. After Jesus prophesies that the magnificent temple will be destroyed, the disciples ask two questions: when will the temple's destruction take place, and what will be the sign of his return ( $\pi \alpha p o v \sigma^{\prime} \alpha$ ) and the end of the age (Matt. 24:2-3). Noah is mentioned in Jesus' answer to the second question immediately after he introduces it with these words: "No one knows about that day or hour (i.e., of his return), not even the angels in heaven, nor the Son, but only the Father" (Matthew 24:36). He then adds, "So it was in the days of Noah, so it will be at the coming of the Son of Man. For in the days before the flood, people were eating and drinking, marrying and giving in marriage, up to the day Noah entered the ark" (Matt. 24:37-38). The time period around the return of the Lord is likened to that at the time of Noah. As Kikawada writes: "The Flood is seen here as an epoch divider and the Son of Man event will be analogous to it; the Son of Man (i.e. Jesus, author added) is another Noah." 11

A comparison of the Greek text in Luke and Matthew reveals that each pericope is independent without copying the other. When Jesus taught about the end of the age and his return before various audiences, he undoubtedly used this topos of Noah on several occasions.

\footnotetext{
9 A minimum of two witnesses was /HMD: alternatief: At least two witnesses were required under biblical law to affirm the truth of a statement (Deuteronomy 17:6; 19:15; Matthew 18:16; 2 Corinthians 13:1; 1 Timothy 5:19; Hebrews 10:28).

10 The linkage of Noah and Lot, absent in Matthew 24, as well as the events connected with each often appeared in Jewish Intertestamental literature (e.g., Testament of Naphtali 3.4-5; 3 Maccabees 2:4-5; Philo, Life of Moses 2.52-65) "as examples of the punishment of the wicked and often also of the redemption of the pious." IH Marshall, The Gospel of Luke. Grand Rapids: Eerdmans, 1978:662.
}

11 IM Kikawada, 'Noah and the Ark,' in DN Freedman, (ed.), The Anchor Bible Dictionary. New York: Doubleday, 1992:4.1129. 


\begin{tabular}{|c|c|}
\hline Luke 17:26-27 & Matthew 24:37-39 \\
\hline 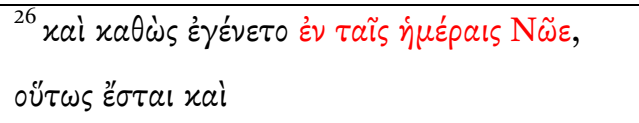 & 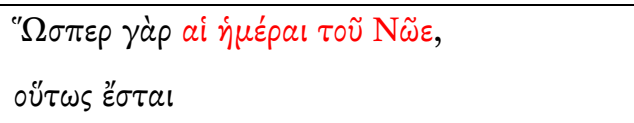 \\
\hline 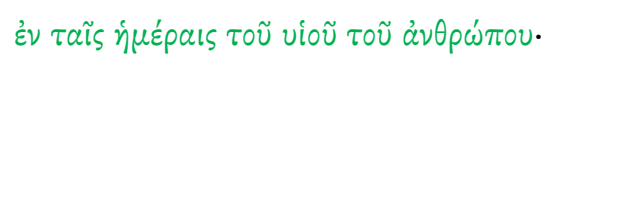 & 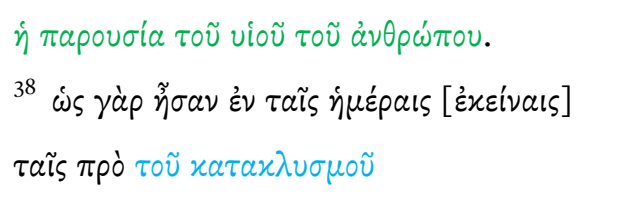 \\
\hline 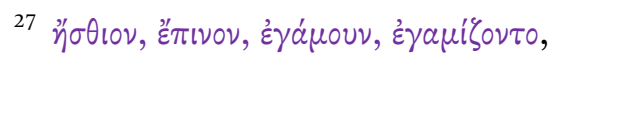 & 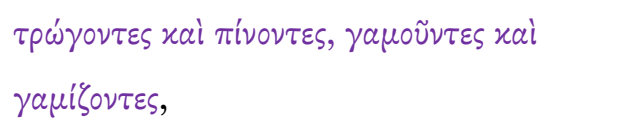 \\
\hline 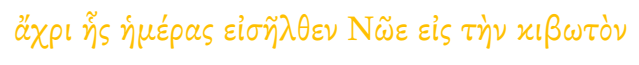 & 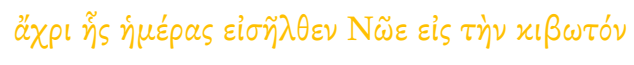 \\
\hline 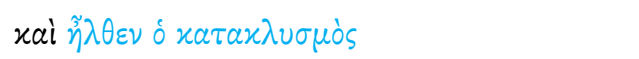 & 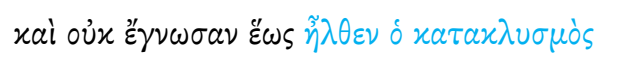 \\
\hline xai ả $\pi \omega^{\prime} \lambda \varepsilon \sigma \varepsilon \nu \pi \dot{\alpha} \nu \tau \alpha \varsigma$. & 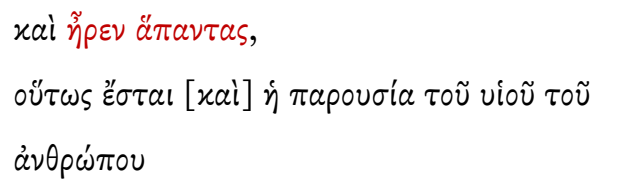 \\
\hline
\end{tabular}

In terms of organization and vocabulary the pericopes are almost identical. Both are introduced with a reference to the 'days of Noah' (red). The phrase 'days of the Son of man' in Luke becomes the 'coming of the Son of Man' in Matthew (green). ${ }^{12}$ Both mention four activities that will occur on earth at the time: eating, drinking, marrying, and giving in marriage (purple). ${ }^{13}$ While these 'normal' affairs of life were going on, Noah 'entered into

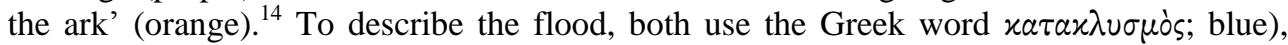
which is used 12 times in the third century BC Greek translation of Genesis (the Septuagint or LXX) to translate the technical Hebrew word מבּוּל ${ }^{15}$ Only in the Luke's version is the result of the flood given: 'it destroyed them all.'

12 The technical term for Jesus' second coming rapovoía, used by Matthew and especially by Paul in the New Testament, is never used by Luke in his Gospel or the book of Acts.

13 The only verbal difference is that Luke uses દ̇ $\sigma \theta^{\prime} \omega$ for eating while Matthew uses its synonym $\tau \rho \dot{\omega} \gamma \omega$.

14 The Hebrew word תבֶב is used 26 times in Genesis chapters 6-9 to denote the enormous, rectangular, box-shaped vessel that Noah entered with his family to escape the flood. In the Hebrew Bible it is distinguished from the more commonly used word for ark, אֶ, which is used particularly for the ark of the covenant. The Greek translators of the Jewish Scriptures chose the Greek word $\chi$ i $\beta \omega \tau$ ós to translate both Noah's boat and the ark of the covenant. Both senses are used by the writer of Hebrews (9:4; 11:7). In secular usage $x$ ı $\beta \omega \tau$ ós later came to be used for the packing cases that carried cargo throughout the Roman Empire. This ambiguity in meaning was later exploited famously in Apamea Celaenae where a tradition developed that the nearby source of the Marsyas River in Phrygia was the final resting place of Noah's ark. Coinage was issued in the early third century whose reverse contained two figures inside an ark ( $\chi$ ı $\left.\beta \omega \tau^{\prime} \varsigma\right)$ with a dove flying above whose beak held an olive branch. To the left the same two figures, certainly Noah and his wife, are standing on dry ground. See P Thonemann, The Maeander Valley. Cambridge: Cambridge University Press, 2011:88-93.

15 Although an Akkadian background for מבוּל has been suggested, its etymology remains uncertain. The flood was such a well-known event that מבוּל generally occurs with the definite article (except in Genesis 9:11,14) 
It seems that on two different occasions Jesus used a similar analogy about Noah to teach his disciples about the conditions on earth before his return. Carroll observes, "The eschatological crisis will resemble these catastrophes seared in Israel's memory." 16 The location of this teaching in Luke is not given but it is outside of Jerusalem. Matthew, however, provides the location - the Mount of Olives opposite the temple in Jerusalem across the Kidron valley. On both occasions Jesus uses 'the days of Noah' as a negative paradigm for the immoderate actions and lackadaisical attitudes of people on earth that will likewise precede his return to earth at the end of the age. As Geldenhuys writes, "As in the time before the Deluge, the great masses of people will, even up to the moment of His advent, be completely engrossed in earthly, material and evanescent affairs and will not take heed to be prepared for His coming." ${ }^{\prime 7}$ On the other hand, Noah and the ark serve as a positive harbinger of deliverance for the righteous who look forward to the day when Jesus will return.

\section{Noah and the Flood in the Book of Hebrews}

The writer of Hebrews in chapter 11 lists Noah among the righteous people in the Jewish Scriptures: "By faith Noah, when warned about things not yet seen, in holy fear built an ark to save his family. By his faith he condemned the world and became heir of the righteousness that comes by faith" (11:7). Noah is third in the encomiastic list of eighteen 'ancients' ( $\pi \rho \varepsilon \sigma \beta u ́ \tau \varepsilon \rho \circ)$ whom the author mentions by name as examples of the kind of

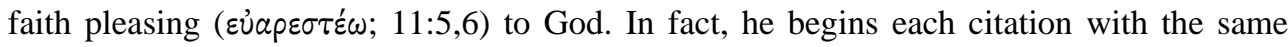

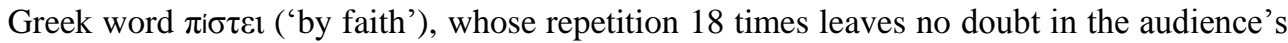
mind what his subject is. The author's enumeration differs from that of Philo who viewed Noah as the first exemplary righteous man (Congr. 90). In Hebrews Noah's name follows those of Abel (11:4) and Enoch (11:5); like Abel he offered a sacrifice that was pleasing to the Lord (Genesis 8:20-21). Noah precedes Abraham who is listed after him as an exemplar of faith (11:8-12). Lewis observes: "There can be little doubt that this picture of Noah has been influenced by Ez. 14:14,20. Its general treatment of Noah's righteousness parallels the ideas of Sir. 44:17 and Wis. 10:4."18

The writer, in these two verses, constructs an intense portrait of Noah's faith. ${ }^{19}$ Like Moses (8:5) and Cain by implication (12:24-25), Noah had been warned ( $\chi p \eta \mu a \tau i \zeta \omega)$ by God to perform a specific action. Since faith was defined in 11:1 as "the evidence of things

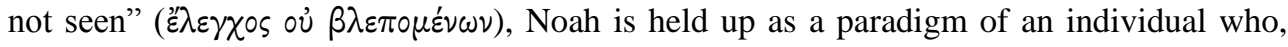
being warned about things not yet seen ( $\left.\pi \varepsilon \rho i \tau \tilde{\omega} \nu \mu \eta \delta \delta^{\prime} \pi \omega \beta \lambda \varepsilon \pi \circ \mu \varepsilon \dot{\nu} \omega \nu\right)$, i.e., the coming flood, did something to save not only himself but also his family. He built an ark motivated by $\varepsilon \dot{\lambda} \lambda \alpha \beta \eta \theta \varepsilon i \varsigma$. This verb, an aorist passive participle, is a hapax legomenon in the New

and is found only once outside Genesis chapters 7-11 in Psalm 29:10. See RL Harris, GL Archer, Jr and BW Waltke, Theological Wordbook of the Old Testament \#1142.0; BibleWorks accessed 6/7/2013.

.

18 Lewis, A Study of the Interpretation of Noah and the Flood, 101. However, the author of Hebrews, as Peters notes, has "reinterpreted the righteousness of Noah but in ways different from the Qumran sectarians." DM Peters, Noah Traditions in the Dead Sea Scrolls, Atlanta: SBL, 2008:4.

19

Johnson rightly notes that some dimensions of the Genesis account are not developed by the author. "Hebrew does not, for example, make use of the plain statement in Genesis that Noah was a righteous man... More fascinating is the author's omission of another phrase in Gen 6:9, namely that Noah was 'perfect' (teleios) in his generation”. Hebrews: A Commentary. Louisville: Westminster John Knox, 2006:284. On the other hand, the focus in Hebrews on Noah's response of faith is not found in Genesis. 
Testament. Two possible nuances are reflected in the various English translations; they emphasize either 'fear' (NIV, ESV, NKJ) ${ }^{20}$ or 'obedience' (NLT; CEV). ${ }^{21}$ The author's two uses

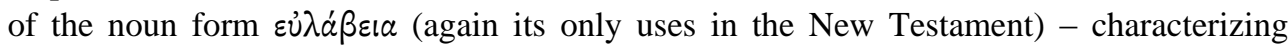
Jesus' response to God (5:7) and how his audience should worship God (12:28) - also suggest both an attitude and an action. So perhaps the best way to characterize Noah's response to the divine warning is to combine both dimensions in translation such as 'with reverent obedience.' Thus motivated, Noah saved his family. The author gives no details about Noah's family, apparently presuming that if his audience were Jews or Gentile Godfearers, ${ }^{22}$ they would know Genesis 7:18 where his family consisted of a wife, three sons - Shem, Ham, and Japheth - and their wives.

The author identifies two spiritual outcomes after Noah heeded God's warning and

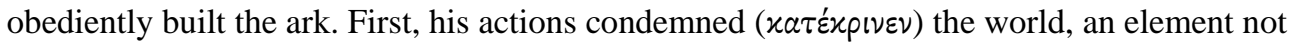
stated explicitly in Genesis. What served as salvation ( $\sigma \omega \tau \eta \rho i \alpha)$ for his family brought condemnation to the world. Those inside the boat were saved, while those outside drowned. ${ }^{23}$ Second, Noah became an heir of the righteousness that comes by faith. ${ }^{24}$ Although Noah is the only one of the eighteen ancients to be called an heir of faith's righteousness, this description would implicitly characterize all the others in his list. By specifically naming only Noah in this regard, the author seems to be in awe of the tremendous act of faith on Noah's part to build such a large boat, despite ridicule by his friends and neighbours, before the rains began to fall. Noah then "is seen as a bridge between the condemned world and the new age.",25

Why is Noah cited as an example to motivate the audience of Hebrews? Since they were told earlier that such former realities and personages were spiritual types (8:5), the author creates a further typological correspondence between Noah's action of building and Jesus' work of salvation. Mosser suggests another possible motivation: "Noah is depicted as the recipient of an oracle warning him about impending destruction. Echoing Noah's commendation, the author uses the same term for the reception of a prophetic oracle $(\chi p \eta \mu \alpha \tau i \zeta \omega)$ when he exhorts this audience not to refuse the one warning them from heaven (12:25). Why? They, like Noah, have been warned about an impending cataclysmic judgment (12:26-27). Salvation from destruction can only be had by obeying the oracle."26 The audience of Hebrews, like Noah, had already suffered ridicule and persecution for their

20 Sibylline Oracle 1.147 interprets Genesis stating that "an immeasurable fear seized the man."

21 The Louw and Nida Greek-English Lexicon of the New Testament, New York: United Bible Societies $2^{\text {nd }}$ ed.

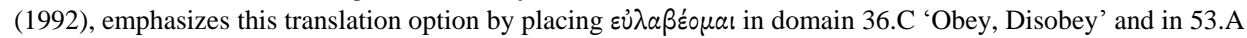
'Religious Practice' with subsequent discussions of each nuance. BibleWorks, accessed 2/7/2013.

22 The identity of the audience of Hebrews continues to be a point of discussion for scholars. That they are all believers, including Jews and Gentile converts/Godfearers, seems the most plausible reconstruction. For a complete discussion see DA Carson and DJ Moo, An Introduction to the New Testament. Grand Rapids: Zondervan, 2005:609-12.

23 For a discussion of the various Jewish interpretations of Noah and his actions, see Johnson, Hebrews, 285-86. Lewis, A Study of the Interpretation of Noah and the Flood, 103, writes, "The passage need imply no more than that the life of the pious is a standing rebuke to the skeptical and impious."

24 The Son has been appointed 'the heir of all things' (1:2), while the Hebrews are the potential 'heirs of the promise' (6:17). Heirship is likewise an important theological concept in Paul's writings (Romans 4:13-14; 8:17; Galatians 3:29; 4:1,7; Titus 3:7), which suggests that the author of Hebrews was probably aware of and influenced by the apostle's teachings.

25 Kikawada, 'Noah and the Ark,' $A B D$ 4.1130.

26 C Mosser, 'Rahab Outside the Camp,' in R Bauckham, DR Driver, TA Hart, and N MacDonald, (eds.), The Epistle to the Hebrews and Christian Theology. Grand Rapids: Eerdmans, 2009:390. 
faith (10:32-35). The author, using the example of Noah, was exhorting them not to turn back to their former religious persuasion. Thus he reminds them that "faith is not just an alternative way to salvation but the only way to salvation. As the story of Noah has already hinted (11:7), all other lifestyles lead to destruction."27 Noah becomes an important case study to make the author's point.

\section{Noah and the Flood in Petrine Literature}

\section{The Ark and Salvation by Water in 1 Peter}

The reference to Noah in Peter's first letter to Christians living in Roman Asia Minor (1:1) is located in one of the most difficult passages in the New Testament to interpret. As Elliott writes, "This complex passage has long challenged scholars and poses a host of questions..."28 While a full discussion of its interpretive points is beyond the scope of this paper, the salient high points will be mentioned. ${ }^{29}$ The text of 3:19-21 reads: "through whom also he (Jesus) went and preached to the spirits in prison who disobeyed long ago when God waited patiently in the days of Noah while the ark was being built. In it only a few people, eight in all, were saved through water, and this water symbolizes baptism that now saves you also - not the removal of dirt from the body but the pledge of a good conscience toward God. It saves you by the resurrection of Jesus Christ."

Several certain observations can be made regarding Peter's mention of Noah. Jesus, after his death and burial, preached to the imprisoned spirits in the same way that Noah preached to the disobedient in his generation $(3: 19-20) .{ }^{30}$ While God waited patiently during the building of the ark, his patience was finally exhausted; and divine judgment came through the torrential rain that fell upon the earth. Out of all the persons who inhabited the earth at this time, only eight were saved from the floodwaters. The other seven are not identified, again suggesting that Peter thought his audience was familiar with

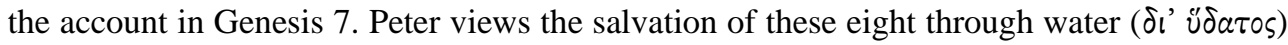

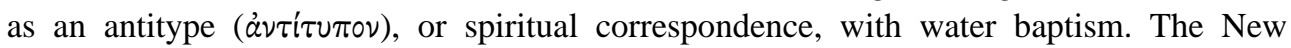
Testament writers regarded the events in the Jewish Scriptures as spiritual types now revealed in Christ. The prophecy of the old covenant is now fulfilled in the Christology of the new. ${ }^{31}$ Such salvation is assured not just through baptismal cleansing but through the resurrection of Jesus Christ. The second clarification seems to be added by Peter, lest someone think that water baptism per se ensured the regeneration of the human spirit. Although only eight were saved in the ark, Peter nowhere hints that the salvation offered through Christ will be limited to a select few. Indeed that his audience, who had certainly

27 L Alexander, 'Prophet and Martyrs as Exemplars of Faith,' in The Epistle to the Hebrews and Christian Theology, 407.

28 JH Elliott, 1 Peter (New York: Doubleday, 2000), 638. KH Jobes likewise writes, “Even among today's interpreters this passage has the reputation for being perhaps the most difficult in the NT.... Moreover, there are an unusual number of textual and lexical difficulties within these few verses" (1 Peter, Grand Rapids: Baker, 2005:236).

29 Elliott provides such a discussion (1 Peter, 638-709), as well as Jobes (1 Peter, 234-60).

30 One line of interpreting this verse suggests that through Noah the pre-incarnate Christ preached repentance to the sinful generation soon to be judged by the flood. Jobes (1 Peter, 239-40) rightly rejects the viability of this interpretation because of its problems handling the Greek syntax in 3:18.

31 Paul likewise understood the OT in this way; see 1 Cor 5:7; 10:6; Rom 5:14. Such a typological interpretation is likewise found in Matt 24:37; Luke 17:26; and 2 Peter 3:6. See Lewis, A Study of the Interpretation of Noah and the Flood, 112-13. 
experienced water baptism subsequent to their acceptance of the gospel, lived far from Israel indicated the universal nature of Jesus' salvation. Suffering $(\pi \dot{\alpha} \sigma \chi \omega ; \pi \dot{\theta} \theta \eta \mu \alpha)$ is a major theme in 1 Peter appearing 15 times $(2: 19-21,23 ; 3: 14,17-18 ; 4: 1,15,19 ; 5: 9-10)$. Noah's salvation through water, despite being mocked and persecuted by his neighbours, would have surely encouraged these besieged believers living in these provinces in Roman Asia Minor. $^{32}$

\section{Noah, the Preacher of Righteousness in 2 Peter 2:5}

The mention of Noah in 2 Peter 2:5 - "if he did not spare the ancient world when he brought the flood on its ungodly people, but protected Noah, a preacher of righteousness, and seven others" - sits between two topoi that we have seen in previous passages. The spirits in prison to whom Jesus is said to have preached in 1 Peter 3:19 are now described in 2 Peter 2:4 as the angels who sinned and were sent to hell to await judgment. A Jewish tradition, preserved in the pseudonymous Intertestamental book of 1 Enoch, mentions a group called the Watchers. This account is an elaboration of the cryptic story in Genesis 6:4 where "the sons of God went to the daughters of men and had children by them." As Wright observes, "The apparent conflict between the 'spirit of God' and 'beings of flesh,' give the strongest indication that the author was using Genesis 6.1-4 as an introduction to the Flood narrative that follows. Humanity and its fleshly nature have created problems in the cosmos and God must deal with them." 33 Jobes notes that "this story immediately precedes the Noah narrative and appears to give justification for the flood." 34 This linkage of the Watcher spirits in prison with Noah thus seems to grow out of the text of Genesis. A subsequent link between Noah and Lot, seen already in Luke 17, likewise appears in the discussion of Lot that follows in 2:6-7.

The spirits in prison, Noah, and Lot are also linked grammatically as part of the long protasis of a conditional sentence starting with El yà (2:4) that runs through verse 9. The apodosis of the conditional sentence is verse 9: "then the Lord knows how to rescue the godly from trial." As Bauckham writes, "Putting the lesson concerning the righteous first enables the writer to end emphatically with the lesson concerning the wicked, applied to his opponents." 35 This then is why the author includes the mention of Noah: the flood account emphasizes how God is able to discern the righteous and the unrighteous by saving the former and destroying the latter.

Regarding several specifics of Noah's presentation in 2 Peter 2:5, first of all, he is called a 'preacher of righteousness.' The Jewish Scriptures nowhere state that Noah preached to those around him. However, several later Jewish writings attribute such a role to him (e.g., Josephus, Antiquities 1.3.1; Genesis Rabbah 30.7; Sibylline Oracle 1.128-29, 145-49, 199). The author uses a classical Greek idiom here: ob $\gamma \delta \circ 0 \nu$ N $\tilde{\varepsilon} \varepsilon$ ('Noah the eighth person') that means 'Noah with seven others.' Both 1 and 2 Peter emphasize the number eight, which is the sum of those rescued, but whose total is never given in Genesis or the Jewish Scriptures and later Jewish writings. This stress, according to Bauckham, "is perhaps to be found in the eschatological symbolism of the number eight, which represented an eighth day of new

32 The topic of Noah's persecution and mocking, despite its absence in Genesis, is picked up also in latter Rabbinical literature (Sanhedrin 108a, b; Pirke de Rabbi Eliezer xxii.;Genesis Rabba 30.7; Leviticus Rabba 27.5; 'Sefer haYashar')

33 AT Wright, The Origin of Evil Spirits. Tübingen: Mohr Siebeck, 2005:91.

34 Jobes, 1 Peter, 244.

35 RJ Bauckham, Jude, 2 Peter. Nashville: Word, 1996:253. 
creation, following the seven days of the old creation's history." ${ }^{26}$ The author sees in Noah a man from the antediluvian world who was protected and preserved to be the first man of the new world after the Flood. Thus he is a "type of faithful Christians who will be preserved from the present world to inherit the new world after the judgment." ${ }^{37}$

One final allusion to the flood occurs in 2 Peter 3:6: "by which (i.e. the waters) the world of that time was deluged with water and perished." This verse is in the midst of a

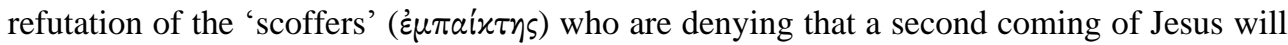
occur. They premise their denial on an uniformitarian perspective: "Everything goes on as it has since the beginning of creation" (3:4). The beginning of creation recalls the events of Genesis chapters 1-2 (cf. Mark 10:6; 13:19). The author reminds them, however, of a flaw in their reasoning. They are deliberately ignoring the fact that God by his word created the

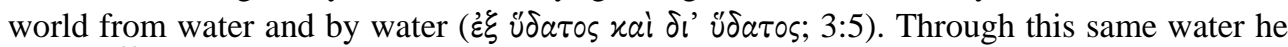
deluged $^{38}$ the same world he had created and destroyed it with judgment. The author then reminds the mockers that a similar judgment and destruction, this time, however, with fire, is awaiting the ungodly (3:7). The author of 2 Peter, according to Bauckham, "seems to envisage world history in three great periods, divided by two great cataclysms: the world before the Flood, the present world which will end in the eschatological conflagration ( $v 7$ ), and the new world to come ( $\mathrm{v}$ 13)." 39 The recollection of the flood here serves the author's parenetic purpose to refute the faulty reasoning of the scoffers. It also frames his argument regarding the two global judgments: one by water in the past in Noah's day, the other by fire in the future at Jesus' return. For "What is important to notice here is that Peter's argument depends on an assumed typological connection between the flood and the final judgment, the days of Noah and the last days. $" 40$

\section{Noah and the Flood in the Apostolic Fathers}

The final references to Noah and the ark are found in The Apostolic Fathers -1 and 2 Clement. First Clement was written to the church in Corinth, a congregation also addressed by the apostle Paul in two canonical letters. Clement's exhortation here is strongly influenced by Sirach 44:17 and Hebrews 11:7. The text of 7:5-6 reads: "Let us review all the generations in turn, and learn that from generation to generation the Master has given an opportunity for repentance to those who desire to turn to him. Noah preached repentance, and those who obeyed were saved." To prove his point, Clement cites two representative examples from the Jewish Scriptures - Noah and Jonah. Noah is again portrayed as a preacher of repentance, as in 2 Peter. ${ }^{41}$ The results of his preaching, however, are more

36 Bauckham, ibid., 250. Early Christians commonly associated the symbolism of the eighth day with Sunday, the Lord's Day; see Epistle of Barnabas 15.9; Justin, Dialogue with Trypho $24.1 ; 41.4 ; 138.1$.

37 Bauckham, Jude, 2 Peter, 250.

38 Regarding the use of this word and its noun form in 2:5, Louw and Nida, Greek-English Lexicon of the New Testament, 14.34 write: "In the NT $\varkappa \alpha \tau \alpha x \lambda u^{\prime} \zeta \omega$ and $\varkappa \alpha \tau \alpha \chi \lambda \cup \sigma \mu o ́ s$ occur only in 2 Peter and are used exclusively of the catastrophic flood in the time of Noah" (BibleWorks, accessed 7/9/2013). The use of each is a hapax in the New Testament; however, it is used of the flood in Wisdom 10:4; Josephus Ant. 5.566;

39 Bauckham, Jude, 2 Peter, 299. He notes further that this periodization with its typological correspondence between the Flood and a coming eschatological judgment is found in some Jewish literature, e.g. 1 Enoch 10:1-11:2 and Sibylline Oracles 1:189-95; 7:7-11.

DR Streett, “As It was in the Days of Noah: The Prophets' Typological Interpretation of Noah's Flood”, Criswell Theological Review 5.7, 2007:34.

41 That the tradition of Noah preaching repentance is found in 1 Clement does not prove that Clement knew 2 Peter, according to Bauckham (Jude, 2 Peter, 251): "On the contrary, his use of $\mu \varepsilon \tau \dot{\alpha} v o$ เav ('repentance') 
open-ended; it sounds like many obeyed and were saved, as in the case of the Ninevites (7:7; cf. Jon. 3:5-10). It would hardly serve his rhetorical purpose to indicate that the fruit of his preaching was only seven persons, all his immediate family!

Two chapters later Clement again introduces Noah: "Let us fix our eyes on those who perfectly served his magnificent glory ${ }^{42} \ldots$ Noah, being found faithful, proclaimed a second birth to the world by his ministry, and through him the Master saved the living creatures that entered into the ark in harmony" $(9: 2,4)$. Clement introduces several elements about Noah not seen in previous texts. First, he uses the language of Genesis 6:9 to describe

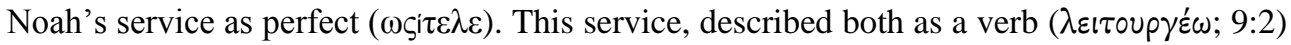

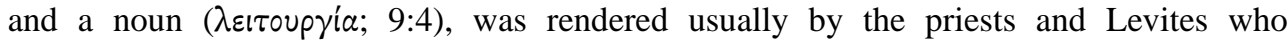
performed their liturgies in the wilderness sanctuary or at the temple in Jerusalem (e.g., Numbers 18:2-6; Luke 1:23). Clement's use of such priestly language suggests that he saw Noah as the first priest of the new world to offer sacrifices to God (Genesis 8:20). Because of this pleasing offering, God promised never again to destroy all living creatures with a flood (8:21). Noah also preached to the world about a second birth. Clement used the Greek word $x \eta \rho v j \sigma \sigma \omega$, used numerous times in the New Testament to speak of the preaching of John the Baptist (e.g, Matt. 3:1), Jesus (e.g., Matt. 4:17), and Paul (e.g., Gal. 2:2. The content of this preaching is said to be $\pi \alpha \lambda \iota \gamma \gamma \varepsilon \nu \varepsilon \sigma i a$. This rare Greek word is used only twice in the New Testament. In Matthew 19:28 Jesus states that there will be a renewal or rebirth of all things at his second coming. Then in Titus 3:5 Paul writes that Christians are saved by the washing of rebirth (e.g., water baptism) and the renewal of the Holy Spirit. Clement's use of $\pi \alpha \lambda \iota \gamma \gamma \varepsilon \nu \varepsilon \sigma i a$ is the spiritual sense in which Paul uses it. The objects of Noah's preaching are said to be the world (xó $\left.\mu \rho_{\varsigma}\right) .{ }^{43}$ As in 2 Peter 3:5, it means primarily the world's inhabitants. But, according to Bauckham, "the word also emphasizes the universal scope of the Flood and invites comparison with the coming eschatological judgment, the second such universal judgment." 44 The parallel between Noah and his family being saved through water in 1 and 2 Peter is likewise reflected here in 1 Clement. Finally, Clement seems to be making the ark an incipient type of the church wherein the harmony (óróvola $)^{45}$ exemplified by the animals should likewise characterize God's people in the church. ${ }^{46}$ It is significant to observe that this is the first time that the animals have been mentioned in these accounts. Noah selected male and female representatives of each species and brought them two by two in an orderly fashion onto the ark. By this act the animal kingdom was spared so that after the flood the animals and birds might repopulate the earth (Gen. 7:8-16; 8:17-19).

shows that he had independent access to the tradition about Noah' preaching. But it is one of many signs that the two documents belong to a common milieu." But this is making too fine a point. Three verses later the author of 2 Peter states, "He (the Lord) is patient with you, not wanting anyone to perish, but everyone to come to repentance" ( $\mu \varepsilon \tau a ́ v o เ \alpha \nu)$. Since repentance is the spiritual outcome for the entire pericope, it is certainly possible that Clement had access to 2 Peter as a literary source.

42 Bauckham (Jude, 2 Peter, 218) notes that Clement shares with 2 Peter a predilection for grandiose terms.

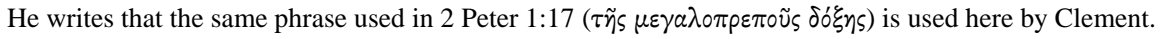
In my view this suggests further that Clement had 2 Peter as a source when he later wrote his letter.

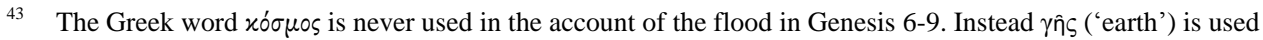
repeatedly throughout these chapters.

44 Bauckham, 2 Peter, 250.

45 The Greek word ópóvola, translated 'harmony' or 'concord,' is never used in the New Testament. However, it is a virtue extolled in Psalm 55:14 (54:15 LXX), Wisdom 18:9, and Sirach 25:1. 
Second Clement contains one reference to Noah. ${ }^{47}$ Chapter 6.8 alludes to Ezekiel 14:1420 and paraphrases verse 20 specifically. This presbyter specifically warns his audience that disobedience to Christ's will can only result in eternal punishment (6.7). He concludes using Ezekiel's references to Noah, Job and Daniel: "Now if even such righteous men as these are not able, by means of their own righteous deeds, to save their children, what assurance do we have of entering the kingdom of God if we fail to keep our baptism pure

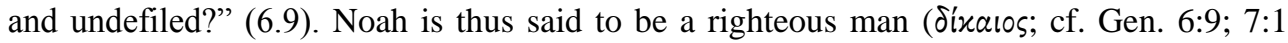

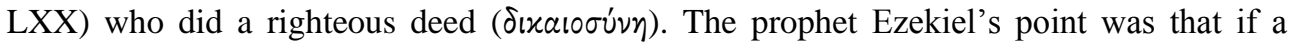
country such as Judah sinned so egregiously against God's commands, even a righteous man like Noah could only save himself.

But would 2 Clement's audience have understood the analogy? Familiarity with the context of the elusive quotation from Ezekiel would certainly have been required. The more familiar story was that of Noah who, in fact, saved his children by the righteous act of building the ark. Nevertheless, the author used the example of Noah as a warning that those who have been saved through water baptism needed to produce fruit consistent with their new life in the Spirit.

\section{Conclusion}

This article has demonstrated that the tradition about Noah, the ark, and the flood was well known to Jesus and the early Christians. For them the Jewish Scriptures were a "valid and literal record of the past. The interpretation given assumed and demanded that it be valid history." ${ }^{48}$ This is particularly true of Jesus who used the flood account to warn that the future judgment would be like that in the antediluvian period.

On the other hand, as Lewis notes, "More interest was displayed ... in the lessons to be drawn from this past than in the literal past itself." 49 He then delineates two purposes for the mention of Noah, the ark, and the flood by early Christian writers - moral and homiletic. Regarding the moral purpose, Noah is portrayed as the exemplary righteous man whose obedience made him a model of faith. Like Enoch and Lot before and after him, Noah believed the divine warning and built the ark that also saved the seven other members of his family. Early Christian authors saw the same forces of unbelief and idolatry at work in their day, so Noah served as a type for their audiences to emulate. As for its homiletic purpose, the portrait of Noah is one of a preacher to his generation. Each writer also saw himself as a preacher whose job was to exhort people to live righteous lives so they would not perish like the ungodly in the flood. False teachers had infiltrated the Christian fellowships and their heterodox teaching was threatening the salvation gained by the believers. Thus their appeals pointedly connected these apostates with those who perished in the flood. Clement's homiletic point regarding the concord of the animals entering the ark is that there should be similar harmony in the church. ${ }^{50}$

Two additional purposes suggest themselves from the aforementioned texts. First is an eschatological purpose. Jesus warned his audiences on at least two occasions that the events surrounding his return would resemble those in the antediluvian period. "The days of

\footnotetext{
47 As MW Holmes notes, "The so-called second letter of Clement is not a letter, nor is it by Clement. It is, in fact, a sermon or 'word of exhortation' composed by an anonymous presbyter (17:3)" (ed). and rev.

The Apostolic Fathers: Greek Texts and English Translations. Grand Rapids: Baker, 1999:102.

Ibid.

$50 \quad$ Ibid., 104.
} 
Noah" thus became an eschatological catch phrase to characterize the laissez faire attitude of the earth's inhabitants who would soon experience unexpected catastrophe. At his second coming ( $\pi$ apovoía) those who were repentant will be saved while the disobedient will be judged. Peter notes that God was patient during the days of Noah as the ark was being built (1 Pet. 3:20). But once it was finished the rains came. Similarly, since the resurrection of Jesus, God has been patient with the world but one day his patience will expire and only those saved and baptized in water will escape the coming judgment.

A final purpose is an ecological one, which accords with the present environmental concerns in our world today. ${ }^{51}$ Noah is portrayed as the saviour of the living creatures who entered into the ark. God's complaint was not with the animal kingdom above, below, and on the earth that he had created on days 5-6 (Gen. 1:20-25). Instead his grievance was with humanity whom he had also created on day 6 (Gen. 1:26-27). The command to rule over the animal kingdom as responsible stewards (Gen. 1:28-30) was violated when humanity polluted the earth with its idolatry. Clement's portrayal of Noah leading the creatures to safety inside the ark proved to be salvation for God's created order as well as for Noah and his family. God promised never to destroy the world again with a flood (cf. Isa. 54:9), thus the inhabitants of the earth must live on this earth until its renewal at the second coming of Jesus. The account of Noah and the flood serves as a reminder not only to people of the monotheistic faiths - Jews, Christians, and Muslims - but also to everyone that we must be stewards of the earth in an environmentally responsible way. The plants, animals, birds, and fish, as creations of God, are to be a blessing to humanity both to use and to enjoy.

51 For example, BR Rossing writes, "The story of Noah and the flood opens up wonderful possibilities for ecological preaching. The flood story culminates in what might be called the original "eco-covenant." NC Habel, D Rhoads, and HP Santmire, (eds.), The Season of Creation: A Preaching Commentary. Minneapolis: Fortress, 2011:114. 